\title{
PENGARUH TEKNIK PEMBELAJARAN COOPERATIVE LEARNING TIPE BERKIRIM SALAM DAN SOAL DALAM MATERI PEMBELAJARAN TEKS ULASAN SISWA KELAS VIII SMP NEGERI 8 PALEMBANG
}

\author{
Yulisar Panuah \\ SMP Negeri 21 Palembang
}

\begin{abstract}
ABSTRAK
Teknik pembelajaran cooperative learning tipe berkirim salam dan soal merupakan teknik pembelajaran di mana melibatkan siswa secara aktif dalam pelaksanaanya yang mana siswa dituntut untuk membuat kelompok belajar yang terdiri atas empat orang dan masing-masing kelompok diwajibkan untuk membuat pertanyaan kemudian kelompok lainnya harus menjawab pertanyaan yang dibuat kelompok lainnya. Rumusan masalah dalam penelitian ini adalah adakah pengaruh teknik pembelajaran cooperative learning tipe berkirim salam dan soal dalam materi pembeajaran teks ulasan siswa kelas VIII SMP Negeri 8 Palembang?. Tujuan penelitian untuk mengetahui ada tidaknya pengaruh teknik pembelajaran cooperative learning tipe berkirim salam dan soal dalam materi pembeajaran teks ulasan siswa kelas VIII SMP Negeri 8 Palembang. Populasi penelitian ini adalah seluruh siswa kelas VIII di SMP Negeri 8 Palembang. Sampel penelitian ini adalah kelas VIII 1 sebagai kelas eksperimen dan kelas VIII 2 sebagai kelas kontrol. Metode yang digunakan dalam penelitian ini adalah metode eksperimen. Teknik data yang digunakan adalah tes. Dari hasil perhitungan statistik uji-t dua pihak, diperoleh $t_{\text {hitung }}=12,93$ dan $t_{\text {tabel }}=2,000$ berarti $t_{\text {hitung }}>$ $t_{\text {tabel }}$ sehingga Ha dapat diterima Ho ditolak. Dengan demikian, Ha dapat diterima berarti ada pengaruh yang signifikan teknik pembelajaran Coopertive Learning tipe berkirim salam dan soal dalam materi pembelajaran teks ulasan siswa kelas VIII SMP Negeri 8 Palembang.
\end{abstract}

Kata kunci : Cooperative Learning, berkirim salam dan soal, teks ulasan

\section{THE INFLUENCE OF COOPERATIVE LEARNING LEARNING LEARNING TECHNIQUES SENDING AND PROBLEMS IN LEARNING TEXT LEARNING MATERIALS CLASS VIII STUDENTS OF JUNIOR HIGH SCHOOL 8 PALEMBANG}

\author{
Yulisar Panuah
}

\begin{abstract}
Cooperative learning techniques type of greetings and questions are learning techniques which involve students actively in their implementation where students are required to make a study group consisting of four people and each group is required to make questions then the other groups must answer the questions made other groups. The formulation of the problem in this study is is there the influence of cooperative learning techniques of sending greetings and questions in the text learning material of the eighth grade students of Junior High School 8 Palembang? The purpose of this study was to determine whether there was an influence of cooperative learning techniques of the type of greetings and questions in the learning material of text reviews for grade VIII students of Junior High School 8 Palembang. The population of this research was all students of class VIII at Junior High School Palembang. The sample of this study was class VIII 1 as an experimental class and class VIII 2 as a control class. The method used in this research is the experimental method. The data technique used is a test. From the results of the calculation of the two-party t-test statistics, $\mathrm{t}$-count $=12.93$ and $\mathrm{t}$-table $=2,000$ means $\mathrm{t}$-count $>\mathrm{t}$-table so that Ha can be accepted Ho is rejected. Thus, Ha can be accepted means that there is a significant influence on the learning techniques of Cooperative Learning type of greetings and questions in the text learning material of students' grade VIII review at Junior High School 8 Palembang.
\end{abstract}

Keywords: Cooperative Learning, sending greetings and questions, review text 


\section{A. PENDAhULUAN}

Pendidikan merupakan bagian integral dalam pembangunan. Proses pendidikan tidak dapat dipisahkan dari proses pembangunan itu sendiri. Pembangunan diarahkan dan bertujuan untuk mengembangkan sumber daya manusia yang berkualitas. (Hamalik, 2015:3) pendidikan adalah suatu proses dalam rangka mempengaruhi peserta didik supaya mampu menyesuaikan diri sebaik mungkin dengan lingkungannya, dan dengan demikian akan menimbulkan perubahan dalam dirinya yang memungkinkannya untuk berfungsi secara adekuat dalam kehidupan masyarakat. Kendatipun dua unsur tersebut sama pentingnya, namun ada kemungkinan pertumbuhan dan perkembangan itu disebabkan oleh bakat saja atau pengaruh lingkungan saja (Hamalik, 2015:3).

Ditinjau dari aspek proses, pendidikan merupakan tindakan dalam rangka mempengaruhi peserta didik. Peserta didik diharapkan mampu menyesuaikan diri sebaik mungkin dengan lingkungannya, dan yang akan menimbulkan perubahan pada dirinya yang memungkinkan, sehingga berfungsi sesuai kompetensinya dalam kehidupan masyarakat. Pendidikan di Indonesia dihadapkan pada berbagai tantangan dan hambatan. Salah satu hambatannya adalah rendahnya mutu pendidikan. Dengan hambatan tersebut akan menjadikan sebuah tantangan bagi pengelola pendidikan untuk meningkatkan mutu pendidikan di Indonesia.

Keberhasilan mutu pendidikan sangat erat kaitannya pada alasan yang selalu berkembang di masyarakat antara lain. Menurut Cropley (dalam Tirtarahardja \& Sulo, 2005:44) alasan keadilan, alasan ekonomi, perubahan perencanaan, perkembangan teknologi, faktor vokasional, kebutuhan orang dewasa dan kebutuhan anak-anak masa awal.

Di samping itu, peningkatan mutu pendidikan juga dipengaruhi oleh kompetensi seorang pendidik dalam mengajar. Tenaga kependidikan merupakan suatu komponen penting dalam penyelenggaraan pendidikan, yang bertugas menyelenggarakan kegiatan mengajar, melatih, meneliti, mengembangkan, mengelola, dan memberikan pelayanan teknis dalam bidang pendidikan. Salah satu unsur tenaga kependidikan adalah tenaga pendidik yang tugas utamanya mengajar (Hamalik, 2015:9). Sebagai pemegang peranan yang sangat penting pendidik juga dituntut untuk menguasai berbagai model dan pendekatan mengajar serta terampil dalam menggunakan alat peraga. Dengan kata lain kualitas pembelajaran tergantung kepada kemampuan pendidik dalam memadukan secara sistematis dan sinergis pendidik, kurikulum, bahan belajar, media, fasilitas, sistem, pembelajaran dalam menghasilkan proses dan hasil belajar yang optimal sesuai dengan 
tuntutan kurikulum. Kurikulum adalah suatu program pendidikan yang disediakan untuk membelajarkan siswa. Dengan program itu para siswa melakukan berbagai kegiatan belajar, sehingga terjadi perkembangan tingkah laku siswa, sesuai dengan tujuan pendidikan dan pembelajaran (Hamalik, 2015:9). Dilihat dari pengertian teknik dan pembelajaran di atas maka teknik pembelajaran dapat diartikan sebagai suatu cara spesifik yang dilakukan seseorang dalam menerapkan suatu metode pembelajaran (Mulyatiningsih, 2014:229).

Menurut Djamarah (2014:365) cooperative learning tipe berkirim salam dan soal, memberi anak didik kesempatan untuk melatih pengetahuan dan keterampilan mereka. Anak didik membuat pertanyaan sendiri sehingga dia akan merasa lebih terdorong untuk belajar menjawab pertanyaan yang dibuat oleh teman-teman sekelasnya. Kegiatan berkirim salam dan soal cocok untuk persiapan menjelang tes dan ujian. Teknik ini bisa di gunakan dalam semua mata pelajaran dan untuk semua tingkatan usia anak didik.

Cooperative learning merupakan suatu model pembelajaran di mana siswa belajar dalam kelompok-kelompok kecil yang memiliki tingkat kemampuan berbeda (Shoimin, 2014:45). Pembelajaran kooperatif merupakan aktivitas pembelajaran kelompok yang diorganisir oleh suatu prinsip bahwa pembelajaran harus didasarkan pada perubahan informasi secara sosial di antara kelompok-kelompok pembelajar yang di dalamnya setiap pembelajar bertanggung jawab atas pembelajarannya sendiri dan didorong untuk meningkatkan pembelajaran anggota-anggota yang lain (Huda, 2014:29). Menurut Shoimin (2014:46-47) langkah-langkah model pembelajaran cooperative learning dapat dilakukan dengan cara (1) Pada awal pembelajaran, guru mendorong siswa untuk menemukan dan mengekspresikan ketertarikan mereka terhadap subjek yang akan dipelajari. (2) Guru membagi siswa ke dalam kelompok heterogen yang terdiri 4-5 orang. (3) Siswa memilih topik pembelajaran untuk kelompok mereka. (3) Tiap kelompok membagi topiknya untuk membuat pembagian tugas di antara anggota kelompok.

Menurut Huda (2014:137) teknik berkirim salam dan soal bertujuan untuk melatih keterampilan dan pengetahuan siswa dengan meminta mereka membuat sendiri pertanyaan-pertanyaan, sehingga mereka akan lebih terdorong untuk belajar dan menjawab pertanyaan yang dibuat oleh teman-teman sekelasnya.

Adapun langkah-langkah yang dilakukan dalam pelaksanaan teknik pembelajaran berkirm salam dan soal menurut Djamarah (2014:365-366) adalah sebagai berikut.

1) Dalam pertemuan kelas besar, guru menyampaikan tujuan pembelajaran yang akan dicapai siswa, 
2) Guru membagi siswa ke dalam beberapa kelompok. Setiap kelompok terdiri atas empat orang dan setiap kelompok ditugaskan untuk menuliskan beberapa pertanyaan (soal) yang akan dikirim ke kelompok yang lain. Guru bisa mengawasi dan membantu memilih soal-soal yang cocok,

3) Kemudian, masing-masing kelompok mengirimkan satu orang utusan yang akan menyampaikan salam dan soal dari kelompoknya,

4) Setiap kelompok mengerjakan soal kiriman dari kelompok lain,

5) Setelah selesai, jawaban masing-masing kelompok dicocokkan dengan jawaban kelompok yang membuat soal,

6) Setelah posisi siswa dikembalikan ke kelas besar, kegiatan diakhiri dengan klarifikasi dari guru.

Adapun langkah-langkah yang akan saya lakukan dalam menggunakan teknik pembelajaran kooperatif tipe berkirim salam dan soal dalam meteri pembelajaran teks ulasan adalah sebagai berikut.

1) Kegitan awal

a) Guru menyampaikan tujuan pembelajaran yang akan dilaksanakan.

b) Guru memilih salah satu dari materi yang akan disajikan yaitu materi pembelajaran teks ulasan, kemudian guru membagi siswa kedalam beberapa kelompok secara heterogen yang masing-masing terdiri dari empat orang atau lebih yang berdasarkan keheterogenan kemampuan akademik selain mempertimbangkan kriteria heterogen lainnya yaitu jenis kelamin, ras dan sebagainya.

2) Kegiatan inti

a) Guru memberikan LKS (dalam hal ini pos-test) kepada siswa, dan memberikan waktu kepada siswa untuk memahami materi pelajaran.

b) Guru menjelaskan materi pembelajaran sesuai RPP, dan guru hanya menjelaskan secara garis besar saja.

c) Guru meminta masing-masing kelompok untuk menyiapkan beberapa pertanyaan terkait materi pembelajaran dalam hal ini ialah materi pembelajaran teks ulasan.

d) Masing-masing mengirimkan salah satu orang utusan dari kelompok yang akan menyampaikan salam dan mengirimkan soal dari kelompoknya kepada kelompok tetanggannya. Kemudian kelompok lainya akan menyelesaikan atau menjawab soal dari kelompok yang membuat dan mengirimkan soal.

e) Setelah selesai, guru meminta salah satu utusan dari masing-masing kelompok untuk mempresentasikan soal kiriman yang telah didiskusikan dan dijawab, kemudian guru 
meminta jawaban dari soal yang dikirimkan oleh kelompok pembuat soal sebagai jawaban pembanding.

3) Kegiatan akhir

a) Guru bersama-sama menyimpulkan materi yang telah dipelajari.

b) Guru mengembalikan siswa kedalam bentuk kelas besar kembali.

Teknik pembelajaran kooperatif tipe berkirim salam dan soal ini merupakan teknik pembelajaran yang menarik dan menyenangkan. Karena siswa diminta untuk membuat yelyel atau nyanyian sebagai ciri atau identitas kelompok masing masing. Hal ini akan meningkatkan kreatifitas yang dimiliki oleh tiap-tiap siswa. Selain itu, dengan adanya salam berupa yel-yel atau nyanyian ini akan menghidupkan suasana kelas menjadi suasana pembelajaran yang menyenangkan.

\section{B. METODE PENELITIAN}

Metode penelitian adalah cara yang digunakan oleh penelitian dalam mengumpulkan data penelitiannya (Arikunto, 2014:203). Metode yang digunakan dalam penelitian ini adalah metode eksperimen. Metode penelitian eksperimen dapat diartikan sebagai metode penelitian yang digunakan untuk mencari pengaruh perlakuan terhadap yang lain dalam kondisi yang terkendalikan (Sugiyono, 2014:107). Sugiyono (2014:112) menyatakan bahwa desain eksperimen yang digunakan dalam penelitian ini adalah Posttest-Only Control Design. Dalam desain ini terdapat dua kelompok yang masingmasing dipilih secara random (R). Kelompok pertama diberi perlakuan (X) dan kelompok yang lain tidak. Kelompok yang diberi perlakuan disebut kelompok eksperimen dan kelompok yang tidak diberi perlakuan disebut kelas control. Pengaruh teknik pembelajaran cooperative learning tipe berkirim salam dan soal dalam materi teks ulasan siswa kelas VIII SMP Negeri 8 Palembang. Eksperimen ini bertujuan untuk mengetahui pengaruh teknik pembelajaran cooperative learnin tipe berkirim salam dan soal siswa kelas VIII SMP Negeri 8 Palembang. Populasi dalam penelitian ini adalah siswa kelas VIII SMP Negeri 8 Palembang berjumlah 124 siswa, dengan jumlah siswa perempuan 82 orang dan laki laki 43 orang. Sampel dalam penelitian adalah kelas VIII 1 laki-laki berjumlah 12, perempuan 19 dan kelas VIII 2 laki-laki berjumlah 10 dan perempuan berjumlah 20 . Dalam penelitian ini, peneliti menggunakan dua kelas sebagai sampel penelitian. Kelas VIII.1 sebagai kelas eksperimen, yakni kelas yang diberi perlakuan dengan menggunakan teknik pembelajaran cooperative learning tipe berkirim salam dan soal sedangkan kelas 
VIII.2 sebagai kelas kontrol hanya menggunakan teknik pembelajaran konvensioal. Teknik pengumpulan data penelitian ini menggunakan teknik tes.

\section{HASIL DAN PEMBAHASAN}

Hasil penelitian ini diketahui uji validitas soal pilihan ganda Setelah diperoleh $r_{x y}$ kemudian dikonsultasikan dengan harga kritik product moment, apabila $r_{x y} \geq r_{\text {tabel }}$ maka dikatakan butir soal itu valid yaitu diperoleh dari $r_{x y}$ dikorelasikan dengan $r_{\text {tabel }}$ product moment dengan $\alpha=5 \%$ diperoleh $r_{\text {tabel }}=0,576$. Dengan $\mathrm{N}: 12$ orang. Jika $r_{x y}>r_{\text {tabel }}$, maka alat ukur dinyatakan signifikan atau valid. Dari 35 soal pilihan ganda peneliti hanya mengambil 20 soal tes yang akan diujikan sebagai tes untuk siswa kelas eksperimen dan siswa kelas kontrol yang akan dihitung tingkat daya kesukaran pada tes pilihan ganda tersebut dari 35 soal tersebut semuanya reabel. Setelah penilaian tes pilihan ganda yang berjumlah dua puluh butir soal, maka peneliti mendapatkan hasil akhir di kelas eksperimen yang menggunakan teknik pembelajaran Coopertive Learning tipe berkirim salam dan soal terdapat dua orang yang di bawah KKM dengan nilai KKM 75.

Setelah penilaian tes pilihan ganda yang berjumlah dua puluh butir soal, maka peneliti mendapatkan hasil akhir di kelas kontrol yang menggunakan teknik pembelajran konvensional dengan nilai tertinggi 75 dan nilai terendahnya adalah 45. Uji normalitas kelas eksperimen Nilai modus pada kelas eksperimen terdapat pada nilai 75- 79 dengan jumlah 9 dan Hasil kemiringan yang didapat adalah $=0,76$. Uji normalitas kelas kontrol diketahui nilai modus pada kelas kontrol terdapat pada nilai 75-80 dengan jumlah 11 Hasil kemiringan yang didapat adalah $=-1,13$ dan dikatakan normal apabila nilai $\mathrm{KM}$ berada diantara -1 dan +1 . Uji homogenitas diketahui derajat kebebasan $\mathrm{dfl}=\mathrm{k}-1=2-1=1$ sedangkan $\mathrm{df} 2=\mathrm{n}-\mathrm{k}=61-2=59$ dengan pengujian dilakukan $\alpha=0,05$ dari daftar $F_{\text {tabel }}$ didapat $F_{0,05(1,59)}=4,00$ dan dari peneliti didapat $F_{\text {hitung }}<F_{\text {tabel }}=4,00$. Dari kedua harga F diperoleh jelas terlihat bahwa $F_{\text {hitung }} \leq F_{\text {tabel }}$. Dengan demikian dapat disimpulkan bahwa varians dalam penelitian ini homogen. Hasil pengujian hipotesis dengan menggunakan rumus uji-t, diperoleh $t_{\text {hitung }}=12,93$ Analisis data uji t dua pihak dengan taraf signifikan $\alpha=0,05$ dan $\mathrm{d} k\left(n_{1}+n_{2}-2\right)=59$ diperoleh hasil $t_{\text {hitung }}=12,93$ dan $t_{\text {tabel }}=$ 2,000. Dengan demikian berarti $t_{\text {hitung }} \geq t_{\text {tabel }}$ sehingga Ho ditolak dan Ha diterima yang artinya"Ada pengaruh yang signifikan dari teknik pembelajaran Coopertive Learning tipe berkirim salam dan soal dalam materi pembelajaran teks ulasan siswa kelas VIII SMP Negeri 8 Palembang”. 


\section{PEMBAHASAN}

Penelitian ini dilakukan pada dua kelas sampel, dimana dalam penelitian sampel menggunakan teknik Cluster sampling dalam teknik ini, random dilakukan atas dasar himpunan atau kelompok dengan tanpa mempertimbangkan besar atau kecilnya jumlah anggota sebuah himpunan atau kelompok, dimana kelas VIII 1 menjadi kelas eksperimen dan kelas VIII 2 menjadi kelas kontrol. Yang menjadi kelas eksperimen diajarkan menggunakan teknik pembelajaran Coopertive Learning tipe berkirim salam dan soal dan sebagai kelas kontrol yang hanya diajarkan dengan menggunakan metode ceramah. Metode penelitian yang digunakan dalam penelitian ini adalah metode eksperimen. Sedangkan jenis eksperimen peneliti menggunakan true experimental design dengan bentuk posttest only control design. Pemilihan penggunaan metode tersebut bertujuan untuk melihat pengaruh hasil belajar siswa pada kelas sampel. Peneliti mengharapkan adanya perbedaan antara hasil belajar siswa kelas eksperimen dengan siswa kelas kontrol.

Berdasarkan hasil tes kelas eksperimen yang menggunakan teknik pembelajaran Coopertive Learning tipe berkirim salam dan soal dapat diketahui bahwa nilai rata-rata nilai post-test siswa kelas eksperimen yaitu kelas VIII 1 sebesar 83,06 dimana nilai tertingginya adalah 100 yang dapat diperoleh 1 orang siswa dan nilai terendahnya adalah 60 dan 70 yang didapat oleh 2 orang siswa. Sedangkan untuk kelas VIII 2 sebagai kelas kontrol yang tidak menggunakan teknik pembelajaran Coopertive Learning tipe berkirim salam dan soal dapat diketahui bahwa nilai rata-rata post-test siswa sebesar 66,5 dimana nilai tertingginya adalah 75 yang didapat oleh 11 orang siswa dan nilai terendahnya adalah 45 yang didapat oleh 2 orang siswa. Hal tersebut menunjukan bahwa hasil belajar siswa dengan pembelajaran menggunakan teknik pembelajaran Coopertive Learning tipe berkirim salam dan soal lebih baik daripada hasil belajar siswa yang menggunakan metode ceramah.

Dari hasil pembelajaran menggunakan teknik pembelajaran Coopertive Learning tipe berkirim salam dan soal ini di kelas VIII 1 sebagai kelas eksperimen dapat dikatakan bahwa sebagian besar siswa dapat menerapkan teknik pembelajaran Coopertive Learning tipe berkirim salam dan soal dalam kegiatan pembelajarannya, hal ini terbukti dari rata-rata post-test yang di dapatkan siswa yaitu 83,06 sedangkan rata-rata hasil belajar siswa kelas VIII 2 sebagai kelas kontrol yaitu 66,5.

Setelah dilakukan pengujian hipotesis maka hasilnya diperoleh hasil $t_{\text {hitung }}=12,93$ dan $t_{\text {tabel }}=2,000$, sehingga Ha dapat diterima Ho ditolak. Dengan demikian, Ha dapat 
diterima berarti ada pengaruh yang signifikan teknik pembelajaran Coopertive Learning tipe berkirim salam dan soal dalam materi pembelajaran teks ulasan siswa kelas VIII SMP Negeri 8 Palembang. Kemudian apabila hasil dari pengujian hipotesis Ha diterima, berarti ada pengaruh teknik pembelajaran Coopertive Learning tipe berkirim salam dan soal dalam materi pembelajaran teks ulasan siswa kelas VIII SMP Negeri 8 Palembang.

Hasil penelitian tersebut bahwa kelas eksperimen yang menerapkan pembelajaran menggunakan model pembelajaran berkirim salam dan soal menunjukan adanya pengaruh signifikan terhadap peningkatan hasil belajar dibandingkan dengan siswa kelas kontrol yang tidak mendapatkan pembelajaran dengan teknik berkirim salam dan soal. Terbukti dari hasil tes akhir diperoleh $\mathbf{t}_{\text {hitung }}=14,83$ dan $\mathbf{t}_{\text {tabel }}=2,0336$ hasil ini menunjukan bahwa adanya pengaruh dalam penggunaan teknik pembelajaran Cooperative Learning tipe berkirim salam dan soal. Dari hasil terdahulu yang merujuk pada kajian relevan yang dapat menguatkan penelitian ini dimana adanya pengaruh dalam hal penggunaan teknik ini dalam sebuah pembelajaran tertentu dalam hal ini memahami teks ulasan siswa kelas VIII SMP Negeri 8 Palembang.

\section{SIMPULAN}

Berdasarkan hasil penelitian yang berjudul "Pengaruh Teknik Pembelajaran Cooperative Learning Tipe Berkirim Salam dan Soal dalam Materi Pembeajaran Teks Ulasan Siswa Kelas VIII SMP Negeri 8 Palembang”, dapat disimpulkan hasil nilai tes siswa kelas VIII 1 SMP Negeri 8 Palembang menunjukkan bahwa dari kedua kelas memiliki perbedaan nilai rata-rata, yaitu untuk kelas eksperimen didapatkan nilai rata-rata sebesar 83,06 sedangkan untuk kelas eksperimen didapatkan nilai rata-rata sebesar 66,5. Hipotesis menunjukan bahwa ada pengaruh yang signifikan teknik pembelajaran Coopertive Learning tipe berkirim salam dan soal dalam materi pembelajaran teks ulasan siswa kelas VIII SMP Negeri 8 Palembang. Hal ini dapat dilihat, dimana setelah dilakukan pengujian hipotesis dengan rumus uji-t hasilnya diperoleh $t_{\text {hitung }}=12,93$ dan $t_{\text {tabel }}=$ 2,000, sehingga Ha dapat diterima Ho ditolak. Dengan demikian, Ha dapat diterima berarti ada pengaruh yang signifikan teknik pembelajaran Coopertive Learning tipe berkirim salam dan soal dalam materi pembelajaran teks ulasan siswa kelas VIII SMP Negeri 8 Palembang. 


\section{DAFTAR PUSTAKA}

Arikunto, Suharsimi. 2014. Prosedur Penelitian Suatu Pendekatan Praktik. Jakarta: Rineka Cipta.

Djamarah, Syaiful Bahri. 2014. Guru dan Anak Didik dalam Interaksi Edukatif. Jakarta: PT Rineka Cipta.

Huda, Miftahul. 2014. Cooperative Learning. Yogyakarta: Pustaka Belajar.

Hamalik, Oemar. 2015. Kurikulum dan Pembelajaran. Jakarta: Bumi Aksara.

Mulyatiningsih, Endang. 2014. Metode Penelitian Terapan Bidang Pendidikan. Bandung: Alfabeta.

Shoimin, Aris. 2014. 68 Model Pembelajaran Inovatif dalam Kurikulum 2013. Jakarta: AR-RUZZ Media.

Sugiyono. 2016. Metode Penelitian Pendidikan. Bandung: Alfabeta.

Tirtarahardja, Umar., dan S.L.La Sulo. 2005. Pengantar Pendidikan. Jakarta: PT Rineka Cipta. 